\title{
KEDUDUKAN MAMAK DALAM MASYARAKAT ADAT NAGARI KAMANG MUDIK MENURUT PERSPEKTIF HUKUM ISLAM \\ "ANALISIS TERHADAP PERGESERAN KEWENANGAN PAMAN SEBAGAI HAKAM DALAM HUKUM KELUARGA
}

\author{
Hayati \\ Mahasiswa Pascasarjana UIN Sultan Syarif Kasim Riau \\ hayati@gmail.com
}

\begin{abstract}
This research uses empirical juridical research methods. Samples taken by purposive sampling. The analysis is done descriptively analysis, which gives an illustration and reveals how the real position of mamak in the indigenous community of Nagari Kamang Mudik according to the perspective of Islamic law analyzes the shifting of uncle's authority as hakam in family law. The results of this study are to find out how the position of mamak as hakam in Nagari Kamang Mudik, to find out what factors cause the shifting of mamak as hakam in Nagari Kamang Mudik, and to find out how a review of Islamic law regarding the position of mamak as hakam in Nagari Kamang Mudik
\end{abstract}

Keywords : Mamak, Uncle as Hakam, Family Law

\section{Pendahuluan}

Mamak mempunyai kedudukan yang vital dalam struktur kekerabatan Minangkabau khususnya da lam hubungan mamak dan keme nakan. (Amir.Syarifuddin, 2006, p. 181) Mamak "paman" adalah sauadara laki-laki dari ibu. (Graves, 2017,p.14)Mamak mempuyai kedu dukan yang sejajar dengan ibu karena beliau saudara kandung. Adat Minangkabau memberikan kedudukan dan sekaligus kewajiban yang lebih berat kepada mamak daripada kepada ibu.

(Amir.Syarifuddin,2006,p.182) Seda ngkan dalam lembaga kepemimpinan kaum,mamak dibagi menjadi empat bagian dan mempunyai fungsi masing-masing yaitu:

1. Tungganai (mamak rumah) adalah seseorang yang dituakan atau yang tertua dalam kelompok satu ibu (urang nan saparui) yang bertugas mengawasi dan memi mpin anak kemenakan di rumah terutama kemenakan perempuan di rumah saudara perempuan (dunsanak nan padusi).Tungganai biasanya tidak bergelar datuk namun dia dipercaya oleh kem enakannya,tidak mementingkan diri sendiri,yang secara tulus memberikan perhatian dan pem binaan dan memimpin kemenakannya,dan pembinaan pada sa nak keluarga atau kemenakannya.

2. Setiap paruik (indu) dalam suku kacik (kecil) dapat pula mendirikan penghulu yang dinamakan peng hulu bawah paruik atau penghulu induk.

3. Penghulu andiko adalah seseorang yang disepakati meyandang gelar sako datuk dalam satu kaum 
Hayati : Kedudukan Mamak Dalam Masyarakat Adat Nagari Kamang Mudik Menurut Perspektif Hukum Islam "Analisis Terhadap Pergeseran Kewenangan Paman Sebagai Hakam Dalam Hukum Keluarga

yang terdiri dari beberapa paruik ${ }^{1}$ (adakalanya hanya satu paruik saja). Ada yang menyebut level ini sebagai tuo indu atau pangka tuo dalam suku kacik $^{2}$ sebagai mamak kepala waris.

4. Kepala suku atau kepala pucuk adalah seseorang

penyan-dang gelar sako datuk yang mula-mula sekali mencacah nagari, yang pada tiap-tiap nagari sekurang-kurangnya ada 4 suku asal yaitu suku gadang,yang berwenang terhadap pengawasan datuk-datuk andiko serta pusako tinggi dalam suku gadang. (Bustamam.Dt.Manidiah., tt, p. 25) Mamak di Minangkabau tidak hanya memelihara dan memimpin anak dari keluarga intinya, tetapi juga memelihara dan memimpin kemenakannya. Penentuan sikap keputusan yang menyangkut hajat orang banyak selalu di bawa penyelesaiannya kepada mamak. Apabila terjadi konflik atau perselisihan pada keluarga, niniak mamak dijadikan oleh seseorang atau kemenakannya tempat bertanya, menjadi penegah dan mencari jalan keluar dengan damai secara kekeluargaan. Sesuai dengan istilah adat Minangkabau niniak mamak nan gadang basa batuah, urang nan cadiak tau pandai, candokio arif bijaksano maukua adia bakato bana, manimbang samo barek, maukua samo panjang, indak kuniang dek kunik, indak lamak dek santan kaduonyo badantiang-

Saparuik berarti berasal dari perut seeorang ibunya nenek (gaek)

2 Suku kacik adalah pecahan dari suku besar atau suku asal pada suatu Nagari. Penghulupenghulu andiko ini dalam suatu kampung terdiri dari beberapa orang, merekalah yang barat sepikul ringan sajinjingdalam sebuah suku gadang (besar). dantiang, tangangnyo maleo-leo (tegas dan bijaksana). ${ }^{3}$ Niniak mamak dijadikan utusan bagi seseorang dalam menyelesaikan masalah untuk bermusyawarah atau berunding mendapatkan kesepakatan jalan tengah atau kedamain.

Tumbuh disilang dengan salisih hukum mehukum manurut adat, ninik mamak harus menyelesaikan sebagaimana dipertuahkan:Kusuik nan kamanyalasai, karuah nan kamampajaniah, Kusuik bulu paruah manyalasikan, kusuai sarang tampuo api manyudahi, Bajanjang naik batanggo turun, salasai dibawah indak paralu kateh, indak salasai di bawah naik kateh (naik banding), kasudahan adat kabalerong, salah ka manusia minta maaf, salah ka Allah minta taubat, indak ado kusuik nan indak salasai, manjadi udang dek penghulu, dago dagi manajadi malu. Sumbang salah laku parangai, apo yang cupak dek panghulu pantang kusuik tak salasai, manggaruk sahabih gauang, marosok sahabih raso, mamaki sudi jo siasek sarato sasi katarangan.

Ini adalah tugas ninik mamak (mamak) dalam menyelesaikan masalah atau perkara. Karena memelihara dan memimpin anak kemenakan adalah tugas penting bagi seorang penghulu atau datuk atau niniak mamak beserta perangkatnya.

(Bustamam.Dt.Manidiah., tt, p. 15)

Menurut P. Dt Rajo Imbang, Ninik Mamak adalah kelompok

\footnotetext{
${ }^{3}$ Penjelasan dari pepatah adat tersebut adalah ninik mamak yang besar berkarismatik, orangyang cerdik dan pandai, memutuskan dengan arif bijaksana dan berkata benar, menimbang sama berat, mengukur sama panjang, tidak kuning karna kunyit, tidak enak sama santan keduanya, tegas dan bijaksana.
} 
penentu setiap keputusan yang menyangkut hajat orang bayak dalam masyarakat. Maka setiap tindak tanduk dan prilaku adat masyarakat harus berdasarkan kesepakatan ninik mamak. Sebaliknya tidak akan terlaksana dan tidak akan di akui ketika pekerjaan menyangkut kepentingan orang banyak tanpa persetujuan ninik mamak nan gadang basa batuah (dibesarkan dan dituakan).

Minangkabau adalah suatu suku yang hidup di Sumatera Barat yang masyarakatnya menganut sistem kekerabatan berbentuk matrilineal.Sistem kekerabatan matrilineal adalah suatu sistem garis keturunan yang menimbulkan kesatuan kekerabatan dimana setiap orang menghubungkan dirinya dengan ibunya, atau suatu bentuk sistem kekerabatan yang ditarik melalui garis keturunan ibu. (AA.Navis.,1984.p.99) Keberadaan ibu bagaikan limpapeh rumah nan gadang (tiang utama pada rumah yang besar) yang melambangkan keturunan seseorang.

(M.Rasjid.Manggis.Dt.Panghoeloe, 1982, p. 106)

Adat inilah yang kemudian di sebut dengan hukum adat. Hukum adat yang sifatnya tidak tertulis ini menjadikan hukum adat bersifat dinamis,sehingga mudah menyesuaikan diri dengan perkembangan yang dibutuhkan zaman.Minangkabau mempunyai ciri khas yang unik dibandingkan dengan hukum adat lainnya di Indonesia. la unik karena dilingkungan adat ini berlaku sistem kekerabatan yang berpengaruh ter hadap sistem perkawinan, kehartabendaan, kepemilikan, kewarisan, pergaulan dan lain-lain.Sistem kekerabatan ini menentukan sistem kemasyarakatan yang ada di Minangkabau. (Hazairin, 1976., p. 14)

Sudah menjadi pemahaman di tengah masyarakat Minangkabau, bahwa nagarinya diatur dalam ketentuan adat yang sudah ada sejak turun temurun. Minangkabau merupakan salah satu yang sampai saat ini memepertahankan adatnya. Adat adalah bagian yang tidak dapat terpisahkan dalam kepribadian orang Minang, "Adat Isitiadat, adat yang diadatkan, adat yang teradat dan adat yang sabana adat" begitu pula dengan agama Islam. Postulat adat yang berlaku dalam mengatur masyarakat Minangkabau adalah, "Adat Basandi Syarak, Syarak Basandi Kitabullah, Syarak Mangato Adat Mamakai". Artinya adat yang dipakai di Minangkabau adalah penjewatahan dari ajaran Islam. Adat dengan syarak tidak bisa dipisahkan karena adat Minangkabau adalah produk budaya berdasarkan Agama Islam (Agama Samawi). Unsur pemimpin di Minangakabau dikenal dengan "Tungku Tigo Sajarangan" (niniak Mamak, alim ulam, dan cadiak pandai) sebagai wadah kepemimpinan Minangkabau, harus kompak dalam kesatuan gerak pembinaan masyarakat dengan berpegang teguh pada "Tali Tigo Sapilin" (Agama, Adat dan Perundang Undangan. (Bustamam.Dt.Manidiah., tt, p. 66)

Adalah hal yang terpantang bagi anggota masyarakat bila ia dikatakan tidak beragama, meskipun kadangkala ada perilakunya tidak sesuai dengan adat dan syarak (Islam) itu sendiri. ${ }^{4}$ Setiap aturan adat tidaklah sama setiap nagari, dalam istilah adat dikatakan "Lain Lubuak lain ikan, lain padang lain

\footnotetext{
4 Wawancara dengan P. Dt. Rajo Imbang di Pakan Sinayan, tanggal 08 Juli 2019
} 
Hayati : Kedudukan Mamak Dalam Masyarakat Adat Nagari Kamang Mudik Menurut Perspektif Hukum Islam "Analisis Terhadap Pergeseran Kewenangan Paman Sebagai Hakam Dalam Hukum Keluarga

Bilalang", namun setiap penentu kebijakan adat berada pada satu titik yaitu ninik mamak, penghulu atau datuk, nan gadang basa batuah nan mamegang ukua jo jangko, nan mamaciak barih jo balabeh, nan mamakai adat jo limbago, kapai tampek batnyo, kapulang tampek babarito". Mengajarkan alua jo patuik mananamkan alua jo patuik, menanamkan raso jo pareso, mahukum adia bakato bana. Akan menumbuhkan kultur budaya yang bermutu baik, berbudi luhur dan akhlak mulia, sesuai dengan fatwa adat yang mengatakan "Adat dipakai baru, kain di pakai usang”, ini adalah unsur kepemimpinan yang dimiliki oleh setiap ninik mamak dalam adat Minangkabau dan jiwa hakim atau hakam yang harus melekat dalam jiwa setiap niniak mamak dalam menjalankan fungsinya, sebagai identitas masyarakat Minang nan indak lapuak dek hujan indak langkang dek paneh yang terkenal berbudi dan relijius. ${ }^{5}$

Adat Minangkabau menerap kan lembaga kepemimpinan berje njang, berjenjang naik bertangga turun yang demokratis. Dalam hal ini dikenal tingkat kepemimpinan suku atau kaum dalam bernagari sebagaimana yang disebutkan dalam wasiat adat "kemenakan barajo ka mamak, mamak barajo ka penghulu, penghulu barajo ka mufakat, mufakat barajo ka nan bana,bana berdiri sendirinyo". 6

Islam mengatur tentang proses penyelesaian seketa perselisihan

\footnotetext{
${ }^{5}$ Wawancara dengan Donri Dt. Sati di Kampuang BarangaiNagari Kamang Mudik,tanggal 9 Juli 2019

${ }^{6}$ Hal ini berarti kekuasaan tertinggi (raja) bagi masyarakat Minangkabau adalah "kebenaran". Kebenaran yang tidak ada tolak bandingnya (berdiri sendiri).
}

yang terdapat dalam al- Qur'an baik dilakukan melalui jalur pengadilan ataupun non pengadilan, penyelesaian sengketa melalui jalur non pengadilan dapat dilakukan oleh hakam. Di dalam al-Qur'an sendiri konsep hakam dengan berbagai bentuknya di sebut dalam tujuh surat. Sedangkan yang menyebut hakam sendiri terdapat dalam surat anNissa' ayat 35 , yang menjelaskan mengenai proses penyelesaian sengketa perselisihan dalam keluarga dengan mengangkat seorang hakam dari keluarga suami dan seorang hakam dari keluarga istri. Secara bahasa kata hakam asal maknanya secara istilah "mencegah sesuatu perbuatan untuk islah (kemaslahatan). (Abi.alQasim.al-Husain.bin.Muhammad.alRaghib.al-Asfahani, tt, p. 167) Hakam dapat disebut juga \& لقضا "ketentuan" (al-Wajiz, 1994, p. 165) menurut istilah hakam diartikan:

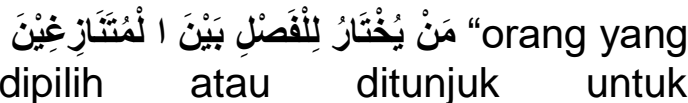
menyelesaikan dua orang yang berselisih paham". (Sa'ad.Abu.Jaib, 1998, p. 96)

Pengutusan hakam dimaksud untuk menelusuri sebab-sebab ter jadinya perselisihan,hakam berusa ha untuk mencari jalan keluar dari permasalahan tersebut agar suami istri dapat berdamai kembali.

DiAdalamAal-Quran permasalahan peran hakam dalam menye lesaikan perselisihan terdapat dalam QS. al-Nisa'(4) ayat 35:

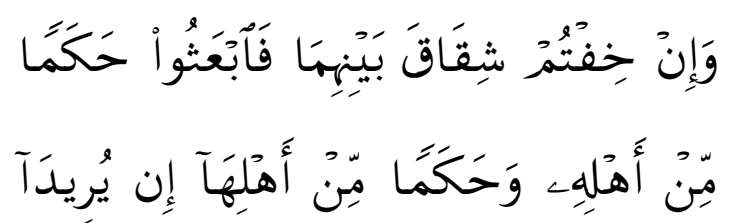




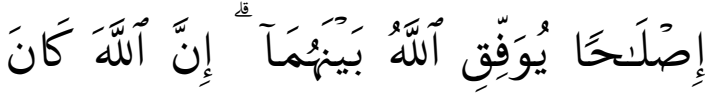

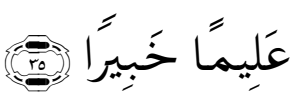

Artinya:

Dan jika kamu khawatirkan ada persengketaan antara keduanya, maka kirimlah seorang hakam dari keluarga laki-laki dan seorang hakam dari keluarga perempuan. Jika kedua orang hakam itu bermaksud mengadakan perbaikan, niscaya Allah memberi taufik kepada suami-isteri itu. Sesungguhnya Allah Maha Mengetahui lagi Maha Mengenal.(Q.S al- Nisa' (04):35). (Depag.RI, 2009, p. 84)

Dalam QS al-Nisa' ayat 35, dinyatakan bahwa hakam itu berasal dari keluarga belah pihak. Pernyataan bahwa hakam dari keluarga sebagaimana disebutkan dalam ayat tersebut menunjukkan bahwa hakam disyaratkan berasal dari kalangan suami dan istri.Meski pada prinsipnya hubungan kekerabatan tidak merupakan syarat sah untuk menjadi hakam dalam penyelesaian sengketa. Tujuan pengutusan pihak ketiga untuk mencapai jalan keluar dari kemelut rumah tangga yang dihadapi oleh suami dan istri, hal ini dapat saja tercapai sekalipun hakamnya bukan dari keluarga kedua belah pihak.

Didalam al-Qur'an tidak ada ayat yang menerangkan untuk bercerai ketika terjadi konflik dalam rumah tangga karena perceraian sangat di benci oleh Allah Swt, melainkan di cari jalan keluar dengan proses damai. (Ahmad.Mustofa.alMaraghy, 1998, p. 49)

Seperti yang dijelaskan dalam firman Allah Surat al- Nisa' ayat 114:

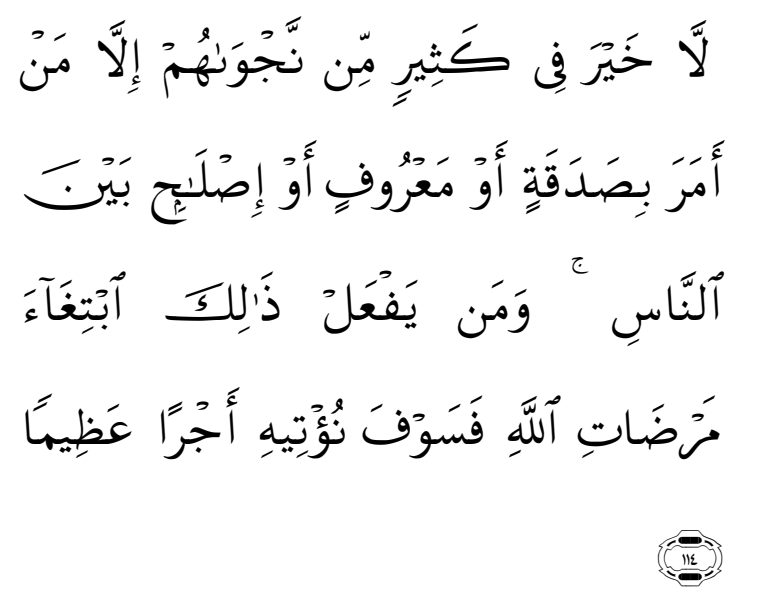

Artinya:

Tidak ada kebaikan pada kebanyakan bisikan-bisikan mereka, kecuali bisikan-bisikan dari orang yang menyuruh (manusia) memberi sedekah, atau berbuat ma'ruf, atau mengadakan perdamaian di antara manusia. Dan barangsiapa yang berbuat demikian karena mencari keridhaan Allah, maka kelak Kami memberi kepadanya pahala yang besar.(Q.S.al-Nisa'(04):114).

(Depag.RI, 2009, p. 97)

Ayat tersebut tidak menjelaskan tentang kebolehan seseorang me njadi hakam, akan tetapi terdapat kalimat yang menegaskan bahwa orang yang menyuruh (manusia) mengadakan perdamaian diantara manusia karena mencari keridhoan Allah maka kelak akan diberi pahala yang besar.Apabila dikaitkan dengan posisi hakam maka tujuan pengangkatan seorang hakam ber sesuaian dengan ketentuan ayat tersebut, karena keberadaan hakam untuk membantu menyelesaikan permasalahan dan mengadakan pe rdamaian diantara para pihak, oleh sebab itu ayat tersebut dapat me njadi landasan diangkatnya seorang hakam karena dalam perkembangan manusia dan seiring perubahan zaman tentuanya banyak terjadi perubahan bahkan terdapat per- 
Hayati : Kedudukan Mamak Dalam Masyarakat Adat Nagari Kamang Mudik Menurut Perspektif Hukum Islam "Analisis Terhadap Pergeseran Kewenangan Paman Sebagai Hakam Dalam Hukum Keluarga

masalahan-permasalahan baru yang tidak mempunyai hukum. Tetapi justru karena tidak ada pengaturan itu maka manusia berhak penuh mengaturnya, termasuk ke dalam kategori yang tidak diatur oleh hukum Islam. (Sudarsono, 1991, p. 278)

Wahbah az-Zuhaili menyatakan bahwa akan lebih bijak bila hakam berasal dari pihak keluarga masingmasing suami dan istri, namun keterlibatan pihak-pihak luar bisa saja terjadi:

"jika keduanya tidak berasal dari keluarga suami dan istri, hakim mengangkat dua orang laki-laki yang bukan keluarga. Baik sekali keduanya berasal dari tetangga suami dan istri, yang mengetahui betul keadaan suami dan istri, serta memilki kemampuan untuk mendamaikan keduanya". (Wahbah.az-Zuhaili., tt, p. 828)

Al- Qurthubi menyatakan lafaz "wa in khiftum" (jika kamu khawatir)" ditujukan pada hakim dan pemerintah/penguasa. Prioritas utama, hakam dari pihak keluarga suami dan istri, bila tidak ada maka bisa diutus orang lain yang 'adil dan alim.

Dua orang hakam yang diangkat juga harus jauh dari subjektifitas maupun tendensi keberpihakan, memilki itikad baik dan tulus untuk tidak saling menyalahkan atau berorientasi memenangkan pendapat pribadi, serta bisa dipercaya untuk menjaga amanat atau hal-hal rahasia dalam rumah tangga suami istri yang bertikai. (Sayyid.Qutb, 1992, p. 56)

Berkaitan dengan hal ini, penulis mendapatkan realita kasus kedudukan mamak sebagai hakam dalam menyelesaikan perselisihan suami dan istri di Nagari Kamang
Mudik, yaitu: Mimi Sulastri berusia (27 th) dan dendi aprio (32 th), pasangan suami istri ini telah menikah selama 3 tahun dan dikaruniai seorang anak laki-laki yang berumur 1 tahun lebih, dalam rumah tangga mereka dari awal menikah sampai 2 tahun dianggap baik tidak ada konflik diantara mereka, namun lama kelamaan muncul perselisihan yang bermula adanya adu mulut antara keduanya, dan merembes kemana-mana. suami langsung keluar dari rumah dan tidak pulang-pulang lagi ke rumah istrinya. Pertengkaran antara mereka tidak kunjung selesai, pada akhirnya keluarga istri mencari jalan keluarnya untuk menjemput kembali suami mimi yang keluar dari rumah. Karena tidak berhasil, mimi menemui mamak rumahnya untuk bisa mencari jalan keluar dari pertengkerannya, setelah diskusi dengan mamak rumahnya mamak rumah mengusulkan untuk menemui mamak kepala suku, keluarga sepakat dan membicarakan masalah ini kepada mamak kepala suku karena dianggap berpengaruh dan bisa memberikan solusi terbaik. Mamak tersebut yang menyelesaikan pertikaian mereka, dengan menasehati kemenakannya dan berbicara langsung dengan mamak sang suami. Dalam penyelesaiannya, kedua mamak menyuruh balik dan bersatu kembali antara mimi dan dendi aprio, salah satu dari pihak keluarga mimi menemani mimi untuk menyemput suaminya. ${ }^{7}$

Peran mamak sebagai hakam dalam keluarga di Nagari Kamang

\footnotetext{
7 Wawancara dengan Donri Dt. Sati di Kampuang BarangaiNagari Kamang Mudik,tanggal 9 Juli 2019
} 
Mudik sangat dibutuhkan karena banyak perselisihan di dalam rumah tangga ataupun dalam masyarakat yang kurang memahami bagaimana cara memberikan solusi yang baik untuk menyelesaikan masalah tersebut. Maka hakam di Nagari Kamang Mudik sendiri adalah mamak (ninik mamak), yang dijadikan mamak disini adalah orang yang dianggap mampu mendamai kan keduanya. Adapun peran hakam di Nagari Kamang Mudik diantaranya dalam menyelesaikan perselisihan seseorang atau anak kemenakan yang menyangkut hajat orang banyak dalam masyarakat .

\section{Mamak Menurut Adat.}

\section{Pengertian Mamak}

Mamak adalah status dan juga merupakan institusi, yang diberikan kepada laki-laki dalam keluarga ibu; yakni saudara laki-laki ibu, bapak saudara sebelah ibu, dan anak lakilaki dari pihak sebelah ibu. (Nurwani.Idris, 2019, p. 14)

Masyarakat hukum adat Minangkabau menganut sistem matrilinieal (sistem keibuan), yaitu suatu sistem dimana keturunan dihitung menurut garis ibu. Mamak adalah sebutan saudara laki-laki dari ibu yang akan berfungsi sebagai orang yang bertanggung jawab terhadap keberadaan keluarga matrilineal dan menjaga serta menambah harta pusaka. Apabila ibu mempunyai saudara laki-laki lebih dari satu orang, maka yang akan bertanggung jawab adalah yang tertua dibantu oleh yang lebih muda. Apabila ibu tidak mempunyai saudara laki-laki namu mempunyai anak- anaklakilaki,makayangakanberfungsisebaga imamakadalahanaklaki- laki tersebut.
(Sri.Sudaryatmi.Sukimo.T.H.Sri.Kart ini, 2000, p. 14)

Menurut adat Minangkabau, bagi seorang laki-laki yang paling dekat kepadanya ialah kemenakannya, yang menurut hukum adat harus mewarisgelar,martabat,keka yaan dan apa saja yang dipunyai mamaknya.Sebaliknya, anaknya sendiri menurut adat bukan seorang anaknya yang sesuku dengan dia dan karena itu menurut hukum adat tidak pusaka mempusakai.Saudara laki-laki ibunya adalah mamaknya dan dia adalah kemenakan saudara laki-laki ibunya. Bagi seorang laki-laki, anak saudara perempuannya merupakan kemenakannya dan dia adalah mamak anak saudara perempuannya.

Anak-anak dari saudara perempuannya dididik dan diasuh oleh mamaknya, sehingga apabila anak-anak itu telah besar, mereka juga akan membalas guna kepada mamaknya atas apa yang telah diberikan mamaknya.Hal ini menimbulkan kewajiban-kewajiban timbal balik antara mamak dengan kemenakan, sehingga akhirnya menimbulkan suatu tertib aturan bermamak berkemenakan. Tertib bermamak berkemenakan ini hanya merupakan konsekuensi saja dari tata susunan masyarakat Minangkabau yang menganut system Matrilineal. (Edison.Piliang, 2013, p. 320)

Adat Minangkabau mengajar kan,bahwa yang dimaksud keme nakan ialah Laki-laki atau perem puan dari pihak ibu yangAdiper tanggungjawabkan oleh mamaknya.

Kemenakan terdiri dari 4 (empat) macam, yaitu :

1. Kemenakan bertali darah, yaitu kemenakan kandung yaitu anak- 
Hayati : Kedudukan Mamak Dalam Masyarakat Adat Nagari Kamang Mudik Menurut Perspektif Hukum Islam "Analisis Terhadap Pergeseran Kewenangan Paman Sebagai Hakam Dalam Hukum Keluarga

anak dari saudara-saudara perempuanmamak.

2. Kemenakanbertalisutera,yaituke menakanjuraiyanglaintapimasih berhubungan darah dengan juraimamak.

3. Kemenakanbertaliemas,yaitukem enakandibawahlutut,orangyang bekerja pada kita dengan diberi mas (uang) dan dengan persetujuannya dijadikankemenakan.

4. Kemenakan bertali budi,yaitu orang-orang yang hidup, mencekam terbang menumpu terjadi dari orang-orang yang pindah dari tempat asalnya ke tempat baru dan di tempat yang baru mencari mamak baru.

(N.M.Rangkoto.Dt.Bandaro, 1984, p. 7)

Mamak adalah laki-laki yang bertanggung jawab menjadi pemimpin kemenakannya baik lakilaki maupun perempuan di pihak ibu dalam lingkungan sosial yang terkecil, kaum, kampung dan sampai lingkungan yang lebih besar seperti nagari. Semua anak-anak baik laki-laki maupun perempuan dari saudara perempuan dipimpin oleh mamak (saudaralaki-laki tertua dari ibu, seperti juga si ayah merupakan mamak bagi kemenakan- kemenakannya di dalam paruiknya). Anak-anak dari saudara perempuan dididik, diasuh dan dipimpin oleh mamaknya, sehingga apabila anak-anak besar, mereka juga akan membalas guna kepada mamak mereka.Oleh karena itu timbullah kewajibankewajiban timbal balik antara mamak dan kemenakan.

\section{Mamak Sebagai Hakam.}

\section{Pengertian hakam}

Secara bahasa kata hakam asal

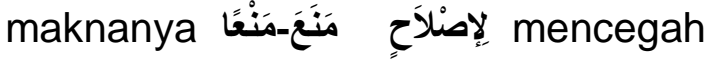
sesuatu perbuatan untuk islah (kemaslahatan). (Abi.al-Qasim.alHusain.bin.Muhammad.al-Raghib.alAsfahani, tt, p. 167) Hakam dapat disebut juga \& لقضا \& "ketentuan". (alMu'jam.al-Wajiz, 1994, p. 165) Menurut istilah hakamdiartikan: مَنْ

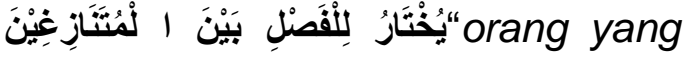
dipilih atau ditunjuk untuk menyelesaikan dua orang yang berselisih paham". (Sa'ad.Abu.Jaib, 1998, p. 96)

Secara istilah para ahli hukum Islam berbeda pendapat dalam mendefenisikan kata hakam, Ahmad Mustofa Al-Maraghi mendefinisikan hakam adalah orang yang mempunyai hak dalam memutuskan perkara antara dua pihak yang bersengketa. (Ahmad.Mustofa.alMaraghy, 1998, p. 40)

Menurut Amir Syarifuddin hakam adalah seseorang bijak yang dapat menjadi penengah dalam menghadapi konflik keluarga. Slamet Abidin dan Aminuddin mendefenisi kan hakam atau hakamain adalah juru damai yang dikirim oleh kedua belah pihak suami isteri apabila terjadi perselisihan antara kedua suami istri tersebut. Defenisi ini hampir sama dengan definisi hakam yang diungkapkan M.A, Tihani dan Sohari Sahrani yang mendefenisikan hakam adalah juru damai. Jadi, hakamain adalah juru damaiyang di kirim oleh dua pihak suami istri apabila terjadi perselisihan antara keduanya, tanpa di ketahui siapa yang benar dan siapa yang salah di antara kedua suami istri tersebut. (M.A.Tihami.Sohari.Sobani, 2000)

Undang-undang No. 7 tahun 1989 yang diubah dengan UU No. 3 tahun 2006 dan diubah lagi UU No.50 Tahun 2009 tentang peradilan Agama 
dalam penjelasan pada pasal 76 ayat (2) memberikan pengertianAhakam, dengan kalimat jelas bahwa hakam adalah orang yang di tetapkan pe ngadilan Agama pihak suami atau pihak keluarga istri atau pihak lain mencari upaya penyelesaian perse lisihan syiqaq. ${ }^{8}$

Hakam (juru damai) merupakan dari rangkaian perkara perceraian dalam perselisihan yang tajam dan terus menerus antara suami istri yang tercantum dalam surat an- Nissa' ayat 35 , menurut Noel J.Coulsen memberi sinonim arbitrator sebagai kata yang sepadan dengan hakam.

Ada beberapa padanan yang mempunyai arti yang hampir sama atau mirip dengan hakam, seperti di kemukakan oleh M. Yahya Harahab memberi sinonim arbitor sebagai kata yang sepadan dengan hakam. Begitu juga Moeteza Mutahhari mengemu kakan padanan hakam dengan kata "arbiter". (M.Yahya.HArahap, 2007, p. 248)

\section{Sejarah Hakam dalam Perka winan}

Ulama berbeda pendapat dalam menentukan kedudukan orang yang diangkat menjadi hakam. Ulama syaf'iyah berpendapat bahwa wajib mengangkat hakam. Sedangkan ulama lainnya mengatakan sunnah, bahkan ulama lainnya sepakat boleh tentang menggunakan hakam sebagai penengah bila terjadi pertikaian suami istri yang terdapat dalam surat al-Nisa' ayat 35 . Dan mereka para ulama sepakat bahwa hakam dari masing-masing pihak suami istri, kecuali tidak terdapat orang yang dijadikan hakam dari kedua pihak, maka boleh mendelegasi pada orang lain. Mereka

\footnotetext{
${ }^{8}$ Undang-undang Nomor 50 Tahun 2009 tentang Peradilan Agama Pasal 76 ayat (2)
}

jumhur ulama sepakat bahwa jika para hakam berbeda pendapat tidak terlaksananya pendapatnya, juga pendapat mereka dalam menggabungkan kedua suami istri terlaksana tanpa diwakili salah satu suami atau istri. Akan tetapi jumhur ulama berbeda pendapat jikalau keputusan hakam adalah untuk memisahkan keduanya, apakah atas izin dan persetujuan dari pihak suami isteri atau tidak? Maka dalam hal ini mereka berbeda pendapat. Menurut Imam Malik dan para sahabatnya boleh. Sedangkan as-Syafi'l, Abu Hanifah dan beberapa para sahabatnya bahwa mereka tidak berhak dalam memisahkan suami istri, kecuali disengaja oleh suami. Dasar hukum Malik adalah hadist dari Ali bin Abi Thalib bahwa beliau mengatakan kepada hakam ada hak untuk menceraikan atau menggabungkan (ruju'). Dalam hal ini as-Syafi'l dan Abu Hanifah bahwa hukum asal (dasar) cerai/talak sang suami atau yang mewakilinya, bukan dari pihak lain. Bahkan sahabat Imam Malik berbeda dalam penjatuhan talak tiga oleh hakam, menurut Ibnu Qasim: Jatuhnya satu. Akan yang lain, mengatakan jatuhnya tiga.

(Ibnu.Rusyd, tt, p. 73)

Jika dilihat dari orang Arab itu sendiri dari lembaga hakam atau arbiter atau penegah sudah ada sejak Nabi Muhammad belum diutus, sejak adanya manusia di dunia pada masa Nabi Adam as, pernah terjadi pertikaian antara kedua anaknya yang bernama Qabil dan Habil. Di mana Nabi Adam as yang menjadi hakam dalam menyelesaikan permasalahan tersebut, hanya saja pada masa itu belum dikenal namanya hakam dan tugas-tugasnya. (Alaiddin.Koto, 2011, p. 17) Bagi masyarakat Arab pada zaman jahi 
Hayati : Kedudukan Mamak Dalam Masyarakat Adat Nagari Kamang Mudik Menurut Perspektif Hukum Islam "Analisis Terhadap Pergeseran Kewenangan Paman Sebagai Hakam Dalam Hukum Keluarga

DOI:10.24014/af.v18.i1.7982

liyah jika terdapat diantaramereka persengketaan atau perselisihan, mereka berpegang kepada tradisi atau kebiasaan dan adat istiadat yang berlaku pada masing-masing kabilah suku. (Alaiddin.Koto, 2011, p. 29)Lebih banyak menunjuk arbiter yang dipilih dari orang yang sudah dipercaya dapat menyelesaikan perkara mereka. Misalnya, seorang pendeta yang mempunyai suprana tural kepada Tuhan. (Noel.j.Coulson, 1991, p. 10)

\section{Pendekatan dan Jenis Penelitian}

Berdasarkan perumusan masa lah dan tujuan penelitian, maka metode pendekatan yang digunakan adalah Yuridis empiris.

(Husaini.Usman.Purnomo.Setia.Akba r, 1995, p. 55) Pendekatan yuridis yaitu hukum hanya Law in book, yakni dalam mengadakan pendeka tan prinsip-prinsip dan peraturan yang masih berlaku dipergunakan dalam meninjau dan melihat serta menganalisa permasalahan yang menjadi obyek penelitian.

Sedangkan pendekatan empiris yaitu pendekatan yang timbul dari pola berfikir dalam masyarakat kemudian diperoleh suatu kebenaran yang harus di buktikan secara nyata di dalam masyarakat. Data-data yang dikumpulkan berbentuk kata-kata, perilaku-perilaku, serta situasi dan kondisi yang menjadi rumusan masalah dalam penelitian ini. Jenis penelitian ini meneliti tentang perilaku sebagian anggota masyarakat yang tidak bisa dinyatakan dalam perhitungan angka-angka, dengan alasan lebih, mudah jika berhadapan dengan kenyataan ganda, menyajikan secara langsung hakikat hubungan antara peneliti dan informan, serta lebih peka dan dapat menyesuaikan diri dengan banyak penerjemahan pengaruh bersama terhadap polapola yang di hadapi. (Lexy.J.Moleong., 2015, p. 5)

Jenis penelitian ini adalah deskriptif analisis, yaitu hasil dari penelitian ini dapat memberikan gambaran secara menyeluruh dan sistematis hukum adat di Minangkabau mengenai kedudukan mamak dalam masyarakat adat Nagari Kamang Mudik menurut perspektif hukum Islam analisis terhadap pergeseran kewenangan paman sebagai hakam dalam hukum keluarga. Kemudian dibahas atau dianalisa sehingga dapat diambil kesimpulan secara menyeluruh.

\section{Lokasi dan waktu penelitian}

Penelitian ini dilakukan di NagariKamang Mudiak Kecamatan Kamang magek Kabupaten Agam Provinsi Sumatra Barat, Nagari Kamang Mudik merupakan salah satu Nagari yang mempunyai 8 (delapan) Jorong. Penentuan objek ini berdasarkan tempat yang penulis pahami dan memudahkan penulis karena lokasi tersebut menyimpan bahan hukum yang diperlukan dan berkaitan dengan kedudukan mamak dalam masyarakat adat nagari kamang mudik menurut perspektif hukum Islam analisis terhadap pergeseran kewenangan paman sebagai hakam dalam hukum keluarga dan tempatnya sangat strategis untuk melakukan penelitian karena adat sangat berperan pada lingkungan tersebut.

Selanjudnya, berkaitan dengan rentang waktu untuk melakukan penelitian, penelitian ini di mulai tanggal 04 Januari 2019 sampai semua data terkumpul atau penelitian ini dirasa telah selesai.

Populasi dan Sampel 
1. Populasi adalah jumlah keseluruhan dari unit-unit yang ciricirinya dapat diduga atau sebagai keseluruhan individu yang menjadi subyek penelitian yang nantinya akan dikenal general generalisa sinya. (IB.Netra, 1976, p. 10)Adapun yang menjadi populasi dalam penelitian ini adalah masyarakat hukum adat dari beberapa suku yang ada di Nagari Kamang Mudik .

2. Sampel, Sampling adalah bagian dari individu atau populasi yang akan diteliti. Purposive sampling yaitu teknik yang biasa dipilih karena alasan biaya, waktu, dan tenaga sehingga tidak dapat mengambil sampel dalam jumlah yang besar yaitu seperti dikemukakan oleh mardalis yaitu

Penggunaan tekhnik purposive sampling mempunyai suatu tujuan atau dilakukan dengan sengaja. Cara penggunaan sampel ini diantara populasi sehingga sampel tersebut dapat mewakili secara karakteristik populasi yang telah dikenal sebe lumnya.Penggunaan tekhnik ini senantiasa kepada ilmu pengetahuan tentang ciri-ciri tertentu yang telah didapat dari populasi sebelumnya. (Ronny.Hanitijo.Soemitro, 1990, p. 11)Adapun yang menjadi sampel adalah Mamak Kepala Kaum dan Kaumnya di Nagari Kamang Mudik.

\section{Data dan Sumber data}

- Data primer yaitu data yang diperoleh dari objek yang diteliti. (Rianto.Adi, 2005, p. 57) Data yang diperoleh langsung dari subjek penelitian dengan menggunakan alat pengukuran atau pengambilan data langsung pada subjek sebagai sumber informasi yang di cari. (Saifuddin.Azwar, 1998) Dalam hal ini, peneliti memperoleh data secara langsung mengamati dan mencatat FenomenaAmelaluiAobservasi (peng amatan), interview (wawancara), dan dokumentasi sehingga didapat data berupa rekaman suara/ gambar, catatan, dokumen, literature kitab tentang hakam, buku tentang Hukum adat Minangkabau dan gambar/foto sebagai data primer karena data-data tersebut sangat sesuai dengan penelitian ini dan sangat tepat untuk mejawab fokus penelitian yang menjadi dasar dalam penelitian ini.

Informan terdiri dari: Wali Nagari, Ketua Kerapatan adat Nagari, penasehat kerapatan adat Nagari, Alim ulama dan Datuak (Niniak mamak) dan masyarakat (informan biasa) yang mengetahui tentang Kedudukan Mamak dalam Masyarakat Adat Nagari Kamang Mudik sebagai Hakam

- Data Sekunder

Data sekunder adalah data yang diperoleh dari tangan kedua atau tangan kesekian. (Winarno.Surahmad, 2000, p. 165) Data ini sebagai hasil penggunaan sumber-sumber lain, bukan merupakan sumber dokumen historis yang murni. Maka dalam hal ini peneliti memperoleh data tersebut dari data-data yang telah ada dan mempunyai keterkaitan dengan masalah yang akan diteliti lebih lanjud melalui literature atau bibliografi.

Alasan peneliti menggunakan literature atau bibliografi sebagai data sekunder karena data-data tersebut dapat memperkuat data-data primer. Sebagai perbandingan untuk datadata primer, dan melengkapi datadata primer sehingga menjadi datadata yang utuh ketika di sajikan.

\section{A. Teknik Pengumpulan Data}


Hayati : Kedudukan Mamak Dalam Masyarakat Adat Nagari Kamang Mudik Menurut Perspektif Hukum Islam "Analisis Terhadap Pergeseran Kewenangan Paman Sebagai Hakam Dalam Hukum Keluarga

Penelitian mengunakan field research (penelitian lapangan) untuk mengumpul data, adapun teknik pengumpulan data dalam penelitian ini penulis menggunakan metode observasi,wawancara,dan dokument asi.

\section{Metode Observasi}

Metode observasi adalah studi yang disengaja dan sistematis tentang fenomena-fenomena sosial, dan gejala-gejala alam dengan jalan pengamatan dan pencatatan.Obser vasi meliputi perhatian terhadapsu atu objek melalui penglihatan,pendengaran,rekaman gambar maupun rekaman suara. (Suharsimi.Arikunto, 2007, p. 128)Penulis mengumpulkan data dengan memperhatikan dan mengamati permasalahan lansung ke lapangan. Dalam hal ini peneliti adalah sebagai pengamat, artinya bahwa peneliti merupakan bagian yang integral dari situasi yang dipelajarinya, sehingga kehadirannya tidak mempengaruhi situasi tersebut dalam kewajarannya. (S.Nasution, 2007, p. 107)

Metode ini digunakan untuk memperoleh data tentang kegiatan Mamak sebagai hakam dalam me nangani masalah hukum keluarga yang terjadi di Nagari Kamang Mudik, serta mengamati kondisi masayara kat mengenai adat dan mengamati budaya setempat.

\section{Interview (wawancara)}

Dalam penelitian ini, peneliti menggunakan model interview bebas terpimpin, di mana pewawancara bebas menanyakan apa saja tetap mengingat akan data yang akan di kumpulkan dengan membawa sederetan pertanyaan.

(Suharsimi.Arikunto, 2007, p. 128)Yang merupakan suatu percakapan, Tanya jawab lisan antara dua orang atau lebih yang duduk berhadapan secara fisik dan diarahkan pada suatu masalah tertentu. Interviu dapat dikatakan pula sebagai bentuk komunikasi verbal yang bertujuan untuk memperoleh informasi. (S.Nasution, 2007, p. 113)Maka,dengan interviu ter-seut dapat memperoleh jawaban dan keterangan dari respnden sesuai dengan tujuan peneliti.

\section{Dokumentasi}

Metode pengumpulan data yang menggunakan bahan tertulis. Didalam melakukan metode dokumentasi, peneliti menyelidiki benda-benda tertulis yang hal ini berupa catatan, traskip, buku, surat kabar, agenda dan lain sebagainya. Dari pengertian diatas dapat diambil pengertian metode ini adalah pengumpulan data dengan cara mengutip, mencatat pada dokumendokumen tulisan-tulisantertentu ynag dapat memberikan bukti atau informasi terhadap suatu masalah.

Adapun dokumen-dokumen yang dapat dijadikan sebagai data dalam penelitian yaitu:

a. Dokumen wawancara dalam bentuk foto, rekaman maupun tulisan.

b. Dokumen interview atas pembanding dari ketua adat dengan perangkat nagari

\section{Metode Pengelolahan Data}

Proses pengelolaan data merupakan proses yang perlu di tempuh untuk menyajikan data. Dalam teknik pengelolaan data yang sudah di sebutkan diatas, dapat dilakukan dengan cara sebagai berikut:

\section{Tahap Edit}

Tahap edit merupakan tahap yang dimaksud untuk meneliti 
kembali data-data yang diperoleh terutama dari segi kelengkapannya, kejelasan makna, kesesuaian serta relevansinya dengan kelompok data yang lain dengan tujuan apakah data -data tersebut sudah mencukupi untuk memecahkan permasalahan yang diteliti dan untuk mengurangi kesalahan dan kekurangan data dalam penelitian serta untuk meningkatkan kualitas data.

Sebelum data diolah, data pengelolaan perlu diedit terlebih dahulu. Dengan kata lain, data atau keterangan yang telah dikumpulkan dalam record book, daftar pernyataan atau interview guide perlu di baca sekali lagi dan di perbaiki jika disana masih terdapat hal-halyang salah atau meragukan. Kerja memperbaiki kualitas data serta menghilangkan keraguan-keraguan data yang dinamakan mengedit data. (Moh.Nasir, 2003, p. 111)

Seluruh data yang berkaitan dengan Kedudukan Mamak dalam Masyarakat Adat Nagari Kamang Mudik Analisa terhadap Kewenangan Paman sebagai Hakam dalam Hukum Keluarga, dapat diambil makna sendiri sebagai kebenaran empirk yang bersifat logik atau teoritik untuk di beri pemaknaan secara intelektual dan diberi argumentasi secara logic. Penekanan pada makna dari hasil penelitian ini dapat menjadi indikator keabsahan dan prediksi data yang akan dipertanggungjawa bkan secara ilmiah.

\section{Tahap Klarifikasi/Coding Data}

Mereduksi data yang ada dengan cara menyusun dan mengklarifikasikan data yang diperoleh kedalam pola tertentu yang mempermudah pembacaanAdanApembahasaanAse- suai dengan kebutuhan peneliti. (Lexy.J.Moleong., 2015, p. 290)

Reduksi merupakan bagian dari anlisis yang menajamkan,menggolo ngkan, mengerahkan, membuang yang tidak perlu, dan mengorganisasi data dengan cara yang sedemikian rupa sehingga kesimpulankesimpulan dapat ditarik dan diverifikasi.

\section{Tahap Verifikasi}

Verifikasi adalah pembuktian kebenaran data untuk menjamin validitas data yang telah terkumpul. (Maria.S.W.Sumardjono, 2001, p. 38) Verifikasi ini dilakukan dengan cara menemui sumber data subjek dan memberikan sumber wawancara dengannya untuk ditanggapi apakah data sesuai dengan yang diinformasikan olehnya atau tidak. Disamping itu, sebagian data penulis memverifikasi dengan cara triagulasi yaitu mencocokkan (cross check) antara hasil wawancara dengan subyek yang satu dengan pendapatan subyek yang lainnya, sehingga dapat disimpulkan proposionalnya.

\section{B. Teknik Analisa Data}

Semua data yang telah diperoleh dan dikumpulkan baik dari data primer yaitu data yang diperoleh secara langsung dari masyarakat atau responden dan data sekunder yang diperoleh dari bahan kepustakaan (Lexy.J.Moleong., 2015, p. 293) serta semua informasi yang didapat dianalisis secara kualitatif yaitu dengan menggunakan data yang diperoleh kemudianAdisusunAsecaraAsistem atis dan selanjutnya ditafsirkan atau di implementasikan untuk menjawab masalah.

Pembahasan dan Hasil

Peranan Mamak sebagai Hakam 
Hayati : Kedudukan Mamak Dalam Masyarakat Adat Nagari Kamang Mudik Menurut Perspektif Hukum Islam "Analisis Terhadap Pergeseran Kewenangan Paman Sebagai Hakam Dalam Hukum Keluarga

\section{a. Kedudukan Mamak Sebagai Hakam Masa Dahulu di Nagari Kamang Mudik}

Di dalam adat Minangkabau peran mamak dahulunya untuk mendidik, membimbing dan menjaga kemenakan, sedangkan saat sekarang ini untuk mendidik anak sudah diambil alih oleh lembaga pendidikan dan orang tua, untuk biaya pendidikan menjadi tanggung jawab suami istri terutama ayah sebagai kepala keluarga, ayah bertanggung jawab atas pendidikan anak-anaknya. Perubahan fungsi keluarga di Kamang Mudik membuat sebahagian peran mamak telah berubah. Jika dalam adat Minangkabau dahulunya ayah hanya bisa ditemui ketika malam oleh anak, karena pada saat subuh ayah sudah keluar dari rumah untuk pergi ke rumah orang tuanya dan kembali saat malam hari. Ayah bertanggung jawab atas kemenakan di rumah gadangnya dan seorang anak akan di pelihara dan dididik oleh mamaknya. ${ }^{9}$

Peran seorang ayah pada saat sekarang ini sudah beralih dan lebih mementingkan keluarga intinya. Adapun hal ini dikarenakan pada saat fungsi mamak sudah beralih, seorang ayah bekerja di tanah pusaka tempat tinggal istrinya tidak lagi di tanah pusaka rumah orang tuanya. Ayahlah yang memelihara dan menjaga anakanak dan istrinya, hal ini sangat berpengaruh pada setiap aspek kehidupan masyarakat. Menguatnya kedudukan ayah dalam rumah tangga sekaligus melemahnya posisi mamak dalam keluarga, ayah lebih dominan dalam pengambilan keputusan serta bertanggung jawab terhadap anggota rumah tangga terutama dalam hal

\footnotetext{
${ }^{9}$ Wawancara dengan Ahmad Latif Dt Samiak di Durian Nagari Kamang Mudik pada tanggal, 25 Juli 2019
}

pendidikan anak dan menafkahi anak. Selain itu, partisipasi ayah semakin besar dalam kegiatan rumah tangga dan semakin menguatnya hubungan antara ayah dan anak. Peran mamak dalam tanggung jawab mencarikan jodoh atau menentukan jodoh kemenakannya pada saat sekarang ini sudah beralih fungsi. Beban dan tanggung jawab dalam perjodohan atau dalam pernikahan pada saat sekarang berada pada keluarga inti. Kemenakan yang sudah dewasa yang sudah ada jodohnya, mamak hanya berperan dalam menyepakati bukan lagi penentu atau yang mencarikan jodoh kemenakan. ${ }^{10}$

Dalam masalah pernikahan di Nagari Kamang Mudik untuk acara resepsi pernikahan tetap melibatkan mamak karena berhubungan dengan orang banyak, dan hal ini telah diatur oleh adat, mamak berperan dalam hubungan sosial antar kelompok orang, di Nagari Kamang Mudik sendiri dalam masalah syariat tidak ada benturan antara Agama dan adat karena adat berbicara antara kelompok orang bukan perorangan. ${ }^{11}$

Dari pengamatan penulis pernikahan yang ditentang oleh mamak di Nagari Kamang Mudik yang tidak bisa dilangsungkan pernikahannya ketika melanggar aturan Adat, dalam adat Nagari Kamang Mudik tidak boleh kawin sesuku. Sesuku yang dimaksud adalah masih dalam wilayah satu kelompok banagari. Adat melarang keras untuk menikah sesuku. Jika pernikahan itu dilangsungkan juga, maka akan ada denda adat berupa

\footnotetext{
10 Wawancara dengan P Dt Rajo Imbang di pakan Sinayan Nagari Kamang Mudik pada tanggal, 22 Juli 2019

11 Wawancara dengan P Dt Rajo Imbang di Pakan Sinayan Nagari Kamang Mudik pada tanggal, 22 Juli 2019
} 
membayar 1 ekor kerbau putih dan penguncilan dalam masyarakat. Apapun yang terjadi dalam keluarga tersebut maka mamak tidak bertanggung jawab, jika ada acara pernikahan tidak akan di hadiri oleh mamak dan masyarakat, bila aturan adat tidak di patuhi. Begitu juga halnya, dalam pertikaian yang terjadi dalam rumah tangga, mamak tidak bisa bertindak langsung untuk menyelesaikan pertikaian kemenakannya dalam masalah yang berhubungan dengan syarak, karena adanya ayah yang lebih dekat dan pastinya lebih mengetahui persoalan tersebut di banding mamak. Jika ayah sudah tidak bisa untuk mendamaikan maka peran mamak baru di butuhkan untuk mencari jalan keluar dari pertikaian tersebut. Contoh perselisihan yang diselesaikan oleh mamak:

1. Kasus baganyi: Mimi Sulastri berusia (27 th) dan dendi aprio (32 th), pasangan suami istri ini telah menikah selama 3 tahun dan dikaruniai seorang anak laki-laki yang berumur 1 tahun lebih, dalam rumah tangga mereka dari awal menikah sampai 2 tahun dianggap baik tidak ada konflik diantara mereka, namun lama kelamaan muncul perselisihan yang bermula adanya adu mulut antara keduanya, dan merembes kemana-mana. suami langsung keluar dari rumah dan tidak pulang-pulang lagi ke rumah istrinya. Pertengkaran antara mereka tidak kunjung selesai, pada akhirnya keluarga istri mencari jalan keluarnya untuk menjemput kembali suami mimi yang keluar dari rumah. Karena tidak berhasil, mimi menemui mamak rumahnya untuk bisa mencari jalan keluar dari pertengkerannya, setelah diskusi dengan mamak rumahnya mamak rumah mengusulkan untuk menemui mamak kepala suku, keluarga sepakat dan membicarakan masalah ini kepada mamak kepala suku karena dianggap berpengaruh dan bisa memberikan solusi terbaik. Mamak tersebut yang menyelesaikan pertikaian mereka, dengan menasehati kemenakannya dan berbicara langsung dengan mamak sang suami. Dalam penyelesaiannya, kedua mamak menyuruh balik dan bersatu kembali antara mimi dan dendi aprio, salah satu dari pihak keluarga mimi menemani mimi untuk menyemput suaminya.

Dalam biaya pernikahan kemenakan mamak tidak berperan lagi dalam membiayai pernikahan kemenakannya. Biaya pernikahan di tanggung oleh keluarga (ayah dari kemenakan tersebut). Sekarang, jika anak bekerja biasanya biaya pernikahan sudah disediakannya disamping orang tua yang bertanggung jawab untuk semua biayanya. Di Nagari Kamang Mudik umumnya di Minangkabau dalam menyelesaikan permasalahan atau konflik dalam urusan rumah tangga suami-istri mamak tetap berperan, tetapi dalam lingkup masalah sosial antar keluarga contohnya suami yang tidak mau diajak untuk bersama sama bergotong royong di lingkungan masyarakat, mamak akan menyelesaikan masalah ini. Akan tetapi Mamak tidak bisa menyelesaikan masalah yang berhubungan dengan syarak seperti contoh tidak terpenuhinya nafkah lahir dan bathin dianatara suami istri sehingga terjadi konflik, permasalahan biasanya di selesaikan di Pengadilan. Ada juga pihak keluarga yang berusaha untuk mendamaikan sebelum ke pengadilan seperti walinya (ayah). Dalam adat Minang menangani permasalahan 
Hayati : Kedudukan Mamak Dalam Masyarakat Adat Nagari Kamang Mudik Menurut Perspektif Hukum Islam "Analisis Terhadap Pergeseran Kewenangan Paman Sebagai Hakam Dalam Hukum Keluarga

akan dilihat persoalannya seperti apa (diidentifikasi) telebih dahulu oleh mamak. Ada istilah yang mengatakan jiko sendok nan bagalegoh ${ }^{12}$ maka disitu mamak tidak bisa ikut campur dalam menangani masalah perselisihan, maka wali yang lebih berhak dalam menyelesaikan masalah tersebut.

Mamak akan berperan dalam menyelesaikan konflik rumah tangga yang berhubungan dengan kelompok orang atau hubungan keluar. Dalam istilah adat mengatakan jiko manyanduak nasi nan tairikkan pariukmaka mamak yang bertindak dalam menyelesaikan.

mamak dalam menyelesaikan perselisihan masih terlibat tetapi penyelesaian pertama akan diselesaikan oleh walinya sebagai orang tua anak, jika pihak keluarga tidak bisa menyelesaikan baru dipanggil mamak dalam menangani masalah tersebut. Tetapi tetap

12 Istilah ini berarti konflik yang terjadi disebabkan karena suami istri dan internal keluarga tidak bisa mamak yang menyelesaikannya. Karena hubungan perorangan bukan hubungan kelompok orang maksudnya, mamak akan bertindak sebagai hakam atau juru damai jika permasalahan itu melibatkan banyak orang atau masalah sosial kelompok orang. Tidak bisa mamak ikut campur terlalu dalam jika konflik rumah tangga yang berhubungan dengan nafkah lahir batin, masalah yang berhubungan dengan syara'. Karena adat mengatur prilaku masyarakat antar kelompok orang, jadi tidak akan pernah syara' berbenturan dengan adat atau adat di benturkan dengan syarak.

${ }^{13}$ Masalah yang berhubungan dengan sosial antar keluarga, mamak yang menaganinya tetapi hanya yang merembes kepada masalah persoalan adat.Jika permasalahan rumah tangga yang menyakut permasalahan sosial kemasyarakatan mamak akan menyelesaikan, diselesaikan secara adat jika perlu di japuil dengan singgang ayam. Wawancara dengan $\mathrm{P}$ Dt Rajo Imbang di Pakan Sinayan, pada tanggal 22 juli 2019
Walinya yang lebih berhak dalam memberikan jalan tengah karena mereka yang lebih tahu dan dekat dengan anak. ${ }^{14}$ Sesuai juga dengan kaidah fiqih yaitu:

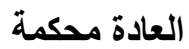

"Adat itu dapat menjadi dasar hukum" (Amir.Syarifuddin, 2006, p. 370)

Adat Minangkabau adalah suatu pandangan hidup yang berpangkal pada budi, begitu juga segala yang ada pada masyarakat di Nagari Kamang Mudik, juga berpangkal pada budi yang mendapat tempat yang utama dalam pergaulan hidup beradat. Adat bagi masyarakat di Minangkabau juga merupakan bagian dari jiwanya.

Dalam pembinaan hukum Islam, kebanyakan ulama mujtahid memakai adat sebagai sumber hukum, bahkan hukum Islam ada juga yang diresapi oleh adat, seperti syarat kafa'ah dalam perkawinan. Sesungguhnya 'urf adat yang memenuhi tiga syarat yang telah ditentukan, dipakai sebagai salah satu sumber hukum. Di antara syarat-syarat tersebut adalah:

1. Ketentuan adat tersebut tidak bertentangan dengan dalil nash

2. Ketentuan adat tersebut telah diketahui dan dibenarkan oleh masyarakat

3. Adat tersebut sudah berlaku secara turun temurun.

Ketentuan adat di atas bukanlah dalil yang berdiri sendiri, akan tetapi ia memelihara tujuan umum hukum Islam (maslahah) sebagaimana yang dikutip dari buku Abdul Wahab Khalllaf: "'urf menurut penyelidikan adalahAtermasukAmasl

\footnotetext{
14 Wawancara dengan P Dt Rajo Imbang di Pakan Sinayan Nagari Kamang Mudik Pada tanggal, 22 juli 2019
} 
ahah sebagaimana di pelihara dalam pembentukan hukum".

(Abdul.Wahab.Khallaf, 1994, p. 137)Dalam bukunya Abdul Wahab Khallaf menerangkan bahwa "apa yang dimengerti secara 'urf adalah seperti yang disyaratkan menurut syara' dan telah tetap menurut 'urf adalah seperti yang telah ditetapkan menurut nash".

(Abdul.Wahab.Khallaf, 1994, p. 137)

Dalam kutipan di atas diungkapkan bahwa apa-apa yang telah dipakai dan dibenarkan secara adat maka hal tersebut dapat dimengerti dan dibenarkan oleh syara', dan apa yang telah berlaku tetap (turun temurun) dalam masyarakat maka dalam hal tersebut telah tetap berlakukanya menurut nash. Pada prinsipnya (secara umum) hukum Islam ini disyariatkan memiliki filosofi untuk mewujudkan kemaslahatan manusia.

Maka dilihat dari kedudukan mamak sebagai juru damai yang diangkat sebagai pemimpin yang di dahulukan selangkah yang ditinggi kan seranting, dapat mencengah dan mendamaikan konflik atau masalah yang terjadi berlarut-larut pada kemenakan dan masyarakat.Maka ke dudukan mamak sebagai hakam di Nagari Kamang Mudik tidaklah me nyalahi prinsip-prinsip atau dasardasar hukum Islam, dan dapat terus untuk dijalankan.

\section{DAFTAR PUSTAKA}

AA Navis, Alam Takambang jadi Guru, (Jakarta Grafiti, 1984)

Abdul Wahab Khallaf, IImu Ushul Fiqh, (Semarang: Toha Putra Group. 1994),

Abi al-Qasim al-Husain bin Muhammad terkenal dengan nama al-Rhagib al-ashfahani, al-
Mufradat fi Gharib al-Qur'an, (tt: Maktabah Nazar Mustafa alBaz, tth), jilid ke-1

Ahmad Mustofa al-Maraghiy, Tafsir al-Maraghiy, terjemahan $\mathrm{K}$. Anshori Umar (Semarang, Tohaputra, 1998) Jilid V.

Ahmad Warson Munawir, Kamus Al Munawir Arab-Indonesia, (Surabaya: Pustaka Progresif, 2002),

Alaiddin Koto (et.al), Sejarah Peradilan Islam, (Jakarta: PT. Raja Grafindo Persada, 2011)

Amir M.S, Adat Minangkabau Pola dan Tujuan Orang Minang, (Jakarta: PT. Mutiara Sumber Widya, 2006)

Bustamam. Dt. Manidiah, B.Sc, Pembinaan Adat Basandi Syarak, Syarak Basandi Kitabullah, Baso: LKAAM Kabupaten Agam

Departemen Agama RI, al-Qur'an dan Terjemahan, (Jakarta: Syaamil Qur'an, 2009)

Edison Piliang, Tambo Minangkabau Budaya dan Hukum Adat di Minangkabau, (Bukittinggi: Kristal Multimedia, 2013),

Elizabeth E. Graves; penerjemah: Novi Andri, Leni Marlina, Nurasni,Asal Usul Elite Minangkabau Modern,cet.ke-I, (Jakarta, Yayasan Obor Indonesia 2017)

Hazairin, Hendak Ke mana Hukum Islam, (Jakarta: Tintamas, 1976)

Husaini Usman dan Purnomo Setia Akbar, Metode Penelitian Sosial, (Jakarta: Bumi Aksara, 1955),

IB, Netra, Statistik Inferensial Usaha Nasional, Surabaya, 1976,

Ibnu Ruysd, Bidayatul Mujtahid wa Nihayah al-Muqtasid, (Semarang: Usaha Keluarga, t.t.), Cet.II 
Hayati : Kedudukan Mamak Dalam Masyarakat Adat Nagari Kamang Mudik Menurut Perspektif Hukum Islam "Analisis Terhadap Pergeseran Kewenangan Paman Sebagai Hakam Dalam Hukum Keluarga

DOI:10.24014/af.v18.i1.7982

Lexy J.Moleong, Metodologi Penelitian Kualitatif (Bandung: Remaja Posdakarya, 2015)

M. Rasjid manggis Dt. Panghoeloe, Sejarah Ringkas Minangkabau dan Adatnya, (Jakarta: Mutiara, 1982)

M. A Tihami, Sohari Sobani, Fiqih Munakahat Kajian Fikih Nikah Lengkap, (Jakarta: PT. Raja Grafindo Persada), Cet. Ke 2,

M. Yahya Harahap, Kedudukan kewenangan dan Acara Peradilan Agama (undangundang no 7 th 1989),(Jakarta: Pustaka Karini, 2007)

Moh Nasir, Metode Penelitian, (Jakarta: Jakarta Bumi Aksara, 2003)

Maria, S.W Sumardjono, Pedoman Pembuatan Usulan Penelitian, (Jakarta: Gramedia Pustaka Utama, 2001)

N.M. Rangkoto, Dt Bandaro, Hubungan Mamak Dengan Kemenakan Dahulu dan Sekarang Serta Pasambahan Adat, (Bukittinggi, 1984)

Noel J. Coulson, A History of Isamic Law, (Endinburg: Endinburg university press, 1991)

Nurwani Idris, Kedudukan Perempuan dan Aktualisasi Politik dalam Masyarakat Matrilineal Minangkabau, (Jurnal Online), dalam http://journal.unair.ac.id/filerPDF 103\%20nurwani\%20Hubungan\% 20Ninik\%20Mamak\%20(Revisi4)\%20 edit\%20mita.pdf

Rianto Adi, Metode Peneltian Sosial dan Hukum,Cet.2, (Jakarta: Granit, 2005)

Ronny Hanitijo Soemitro, Metode Penelitian Hukum dan Jurimetri, (Jakarta: Ghalia Indonesia, 1990)
Sa'ad Abu Jaib, al-Qamus al-Fiqhy Lughatan wa Ishtilahan, (Suriyah: Dar al-Fikr, $1419 \mathrm{H} / 1998$ M), lihat juga, Muhammad 'Ali Shabuny, Rawai' al- Bayan Tafsir Ayat alAhkam min al-Qur'an, (Beirut: Muassasah Manahil al-Irfani, $1400 \mathrm{H} / 1980 \mathrm{M})$, cet. Ke-3,

Saifuddin Azwar, Metode Penelitian, Cet.I, (Yogyakarta: Pusataka Pelajar, 1998),

Sayyid Quthb, Fi Zhilalil Qur'an, Juz III, (Beirut : Dar Asy-Syuruq, $1412 \mathrm{H} / 1992 \mathrm{M})$

Sri Sudaryatmi, Sukirno, T.H. Sri Kartini, Beberapa Aspek Hukum Adat,(Badan

Penerbit Universitas Diponegoro Semarang, Semarang, 2000),

Sudarsono, Hukum Kekeluargaan Nasional (Jakarta: Rieneka Cipta, 1991)

Suharsimi Arikunto, Suhardjono \& Supardi, Penelitian Tindakan kelas, (Jakarta: Bumi Aksara, 2007)

S. Nasution, Metode Research Penelitian Ilmiah, (Jakarta: Bumi Aksara, 2007)

Tim Penyusun Kamus Besar Bahasa Indonesia, (Jakarta: Depertemen Pendidikan Nasional dan balai pustaka, edisi ke III, 2003),

Undang-undang Nomor 50 Tahun 2009 tentang Peradilan Agama Pasal 76 ayat (2)

Wahbah Zuhail, Al- figh al -Islami Waadillatuhu, (Damaskus: Dar Fikr al- Mu asir, t.t),

Wawancara dengan Ahmad Latif Dt Samiak di Durian Nagari Kamang Mudik pada tanggal, 25 Juli 2019

Wawancara dengan P Dt Rajo Imbang di pakan Sinayan Nagari Kamang Mudik pada tanggal, 22 Juli 2019 
Al-Fikra: Jurnal IImiah Keislaman, Vol. 18, No. 1, Januari - Juni, 2019 (106-124) DOI:10.24014/af.v18.i1.7982 